Type of the Paper (Article)

\title{
Effects of metals from oil to polluted soil
}

\author{
Anca Dumitru ${ }^{1}$, Timur Chis ${ }^{2 *}$, Ancaelena Eliza Sterpu ${ }^{3}$ and Olga Valerica Săpunaru ${ }^{4,}$ \\ 1 Quality Department, Oil Terminal S.A. Constanta, Romania; 02iuly1981@gmail.com, \\ 2 Chemical and Chemical Engineering Department, Ovidius University Constanta, Mamaia Blv. 124,Con- \\ stanta, 900527 Romania; timur.chis@gmail.com, \\ 3 Chemical and Chemical Engineering Department, Ovidius University Constanta, Mamaia Blv. 124,Con- \\ stanta, 900527 Romania; asterpu@univ-ovidius.ro, \\ 4 Chemical and Chemical Engineering Department, Ovidius University Constanta, Mamaia Blv. 124,Con- \\ stanta, 900527 Romania; aolgutasapunaru@yahoo.com, \\ * Correspondence: timur.chis@gmail.com ; Tel.: 0040.723.670107,
}

\begin{abstract}
Oil pollution of extraction areas is an undesirable phenomenon, but very present, especially in old farms. In the context in which the depollution of these areas, in Romania, is carried out from public funds, this fact is more and more difficult to achieve. That is why the effect of pollutants on the environment is being analyzed more and more, it often remains that the depollution is done naturally. This material analyzes the effect of metals present in crude oil $(\mathrm{Cu}, \mathrm{Pb}, \mathrm{Zn}, \mathrm{Ag}, \mathrm{Ni}, \mathrm{Mn}, \mathrm{As}, \mathrm{Cd}, \mathrm{V}, \mathrm{Cr}, \mathrm{S})$, on the soil affected by a historical accidental pollution in the Moinesti area, Romania. This article presents the results of analyzes performed by metal detection techniques, namely optical emission spectrophotometry with inductive coupled plasma and atomic absorption spectrophotometry. The metals determined in the polluted soil were statistically analyzed regarding the dispersion, standard deviation and coefficient of variation compared to the control sample and compared with the results from two areas in Romania. The risk of exploitation of polluted areas was also analyzed, namely the method of pollution indices and the method of combining the effects of pollutants.
\end{abstract}

Keywords: metals, oil, pollution, soil.

\section{Introduction}

Crude oil is defined as a solution consisting of hydrocarbons, metals, non-metals, water [1].

If we were to fully analyze the crude oil extracted from all areas of the earth, we would probably determine more than half of the elements of the periodic table, with concentrations ranging from high percentages of carbon and hydrogen and low percentages of nitrogen and sulfur. Transitional metals would also be determined.

Metal constituents were identified in crude oil ( $\mathrm{Na}, \mathrm{Li}, \mathrm{Be}, \mathrm{Mg}, \mathrm{Ca}, \mathrm{Ba}, \mathrm{Sr}, \mathrm{Cu}, \mathrm{Ag}, \mathrm{Zn}$, $\mathrm{Cd}$, Se, Y, La, B, Al, Si, Sn, Pb, Cr, Mo, W, Fe, Co, Ni, Ti, V, Mn), the most abundant being nickel and vanadium $[2,3]$.

Metal constituents are in different percentages in different areas of exploitation around the world, but may differ in the same deposit (Table 1).

Metals can provide information on crude oil migration and its age [4].

T.F.Yen was able to show that the metals in crude oil can be grouped into petroporphyrins and neporphyrins. Thus, five classes were determined, namely [5]:

- metalloporphyrin chelates $(\mathrm{V}, \mathrm{Ni})$,

-complex metal complexes, small tetradentate ligands ( $\mathrm{V}, \mathrm{Ni}, \mathrm{Fe}, \mathrm{Cu}, \mathrm{Cr}, \mathrm{Co}$ ),

-carboxylic acid salts of the functional polar groups of resins (Mo, $\mathrm{Zn}, \mathrm{Ge})$,

colloidal minerals (silica and $\mathrm{NaCl}$ ),

-organometallic compounds ( $\mathrm{Hg}, \mathrm{Sb}, \mathrm{As})$. 
Porphyrins are the first compounds isolated from crude oil that have demonstrated the organic nature of crude oil.

Porphyrin is a macrocyclic system consisting of four pyrrole rings linked by four methine groups, being a class of nitrogen-derived macrocycles. Porphyrins can accept two hydrogen ions to form a diacid with +2 charge or they can give up two protons to become a -2 anion with charge. This characteristic of porphyrins leads to the formation of organometallic complexes with a structure similar to hemoglobin in the blood and that of chlorophyll in green plants. Porphyrins in crude oil demonstrate its formation at low temperatures from organic matter (at high temperatures, porphyries decompose) [6].

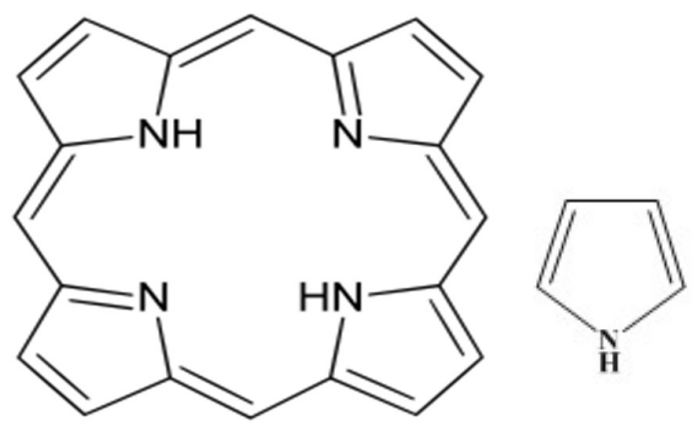

Figure 1. The structure of porphyrin and the pyrrole group [6].

Non-porphyrins in crude oil include other ring systems such as strongly substituted porphyrins. Porphyrins with UV properties other than those mentioned above and porphyrin decomposition products is detected in oil samples [7].

Asphaltenes have bound in their composition metals such as vanadium, nickel and iron which vary in amounts from 5 ppm to several thousand. Asphalt metals are partially bound in porphyrins, which are an integral part of them [8].

Table 1. Concentration of metals ( $\mu \mathrm{g} / \mathrm{g})$ in crude oil from various regions [9]

\begin{tabular}{cccc}
\hline Elements & $\begin{array}{c}\text { California, } \\
\text { USA }\end{array}$ & Lybia & $\begin{array}{c}\text { Alberta, } \\
\text { Canada }\end{array}$ \\
\hline $\mathrm{Na}$ & 13.3 & 13.0 & 3.62 \\
\hline $\mathrm{Ni}$ & 98.4 & 49.1 & 9.38 \\
\hline $\mathrm{Cu}$ & 0.93 & 0.19 & 0 \\
\hline $\mathrm{Fe}$ & 68.9 & 4.94 & 10.8 \\
\hline $\mathrm{Mn}$ & 1.20 & 0.79 & 0.01 \\
\hline $\mathrm{Zn}$ & 9.76 & 62.9 & 0.046 \\
\hline $\mathrm{Cd}$ & 0.004 & 0 & 0 \\
\hline
\end{tabular}

\section{Materials and Methods}

\subsection{Geology of structures}

The analyzed area is placed in Moinesti city, parts of bacau Conty, Romania. Area is parts of the External Unit of the Eastern Carpathian Flysch, being constituted by three folds oriented north-south, with faulted flanks.

The deposits that make up the analyzed structure belong to the Eocene, Oligocene and Miocene [10].

The Eocene appears in the facies of the Bisericani (Church) Layers, being made up of black and green shale marls, micaceous, slightly sandy.

The Oligocene develops under the characteristic facies known in the External Unit of the flysch, being composed of the following horizons: 
1. the horizon of the Lucăceşti sandstone - with a thickness of about 10 - 15 m, made up of a sandstone complex,

2. the horizon of white bituminous marls, up to $150 \mathrm{~m}$ thick,

3. the horizon of the disodils and lower menilites, with a thickness of about $50 \mathrm{~m}$, consisting of bituminous clay rocks and weak intercalations of Kliwa sandstones,

4. the horizon of Kliwa sandstone, with a thickness of about $350 \mathrm{~m}$, consisting of alternations of banks with siliceous sandstones and packages with disodiles ,

5. the Suprakliwa horizon with a thickness of about 59 - $112 \mathrm{~m}$, made up of alternations of Kliwa tiles with disodiles,

6. the horizon of the disodils and upper menilites, consisting of disodilic schists, with intercalations of menilites and intercalations of Kliwa sandstone ,

The Transition horizon, with a thickness between 22 and $46 \mathrm{~m}$, formed by intercalations of microconglomerates, siliceous sandstones, clays and disodiles .

The Miocene consists of blackish compact clays and marls, with intercalations of compact sandstones and salt.

The oil area deposits consists mainly of siliceous sandstones with a higher clay content, so that the flow properties are slightly diminished by the horizons of the SupraKliwa and Kliwa sandstones which have an insignificant volume of clay.

The extraction of crude oil took place between 1960-2000, after which it was abandoned.

No soil decontamination was performed because the concentration in petroleum substances was below the intervention threshold, ie below $1000 \mathrm{mg} / \mathrm{kg}$ dry matter (the land being a less sensitive area).

The oil extraction and treatment facilities were removed and the land was cultivated with flowers (marigolds).

Soil samples were collected using geological probes at a depth of $100 \mathrm{~mm}$ from 12 places located in an oil extraction and treatment area.

The treatment of the soil samples taken in order to perform the analyzes was performed according to the standard SR ISO 11464/1998 - Soil quality.

Pretreatment of samples for physico-chemical analyzes. Thus, the samples were oven dried and crushed with an electric soil mill.

\subsection{Atomic absorption spectrophotometry}

The determinations were performed using a Shi-madzu AA-6300 double beam spectrophotometer (Shimadzu Corporation, Japan).

It is equipped with: ASC-6100F autosampler, flame atomizer and graphite furnace, deuterium lamp for background correction and cavity cathode lamps for the studied elements.

The method SR ISO 8288: 2001 was used to determine copper and zinc. SR EN 14083: 2003 and SR EN ISO 15586: 2004 methods were used to determine cadmium and lead, with modifications to suit the type of matrix analyzed.

Each determination was performed in three repetitions.

For the calibration, 5 concentrations of the reference solutions were used, the correlation coefficients of the calibration rights being in the range 0.9780-0.9997.

To evaluate the degree of recovery of heavy metals from the analyzed soils, a series of samples were created with solutions of known concentrations of these metals, the recorded recovery degrees being: $91.14 \%$ for $\mathrm{Cd}$, over $93.52 \%$ for $\mathrm{Pb}, 94.92 \%$ for $\mathrm{Cu}$ and 95.02\% for $\mathrm{Zn}$. 


\subsection{Inductively coupled plasma optical emission spectrophotometry}

Initial determinations of macro and microelements were made by inductively coupled plasma optical emission spectrometry using a Perkin Elmer Op-tima 5300 DV spectrometer.

The wavelengths used for each element are the following: Ca - 315,887 nm, Cu 327,393 nm, Cr - 267,716 nm, Mn - 257,610 nm, Ni - 231,604 nm, Pb -217.00 nm and Zn $206,200 \mathrm{~nm}$.

\subsection{Analysis of experimental data}

Atomic absorption spectrophotometer control, data acquisition and analysis.

Primary spectral data was performed using WizAArd (Shimadzu Corporation, Japan).

The quantitative data matrix was processed in Microsoft Excel (Microsoft) for statistical calculations (arithmetic mean calculation, standard deviation, Pearson correlation coefficient).

The Pearson coefficient was used to characterize the correlations between the measured contaminant concentrations.

\subsection{Analysis of the environment polluted with metals}

The exploitation of crude oil is a set of operations that can lead to soil and groundwater pollution.

The interest of researchers to study the risk of environmental pollutants is well known, the research works being focused on determining the hydrocarbon content in soil and plants and less on those dedicated to qualitative and quantitative analysis of soil and plant metal content $[11,12]$.

The studies focused on the development of a model for assessing the risk of pollutants determined from oil, for certain study areas.

A model for assessing the risk in exploitation of the land affected by pollution, on the Bayesian model was developed by Aguilera [13] and developed by Diana Mariana Cocârță [14].

An analysis of a land, which must be returned to use after the completion of onshore operations includes in addition to determining the content of petroleum products and determining 14 elements of the periodic table, namely $\mathrm{Cu}, \mathrm{Pb}, \mathrm{Zn}, \mathrm{Ag}, \mathrm{Ni}, \mathrm{Mn}, \mathrm{As}, \mathrm{Cd}, \mathrm{V}, \mathrm{Cr}$ and S [15] (figure 2 and table 2).

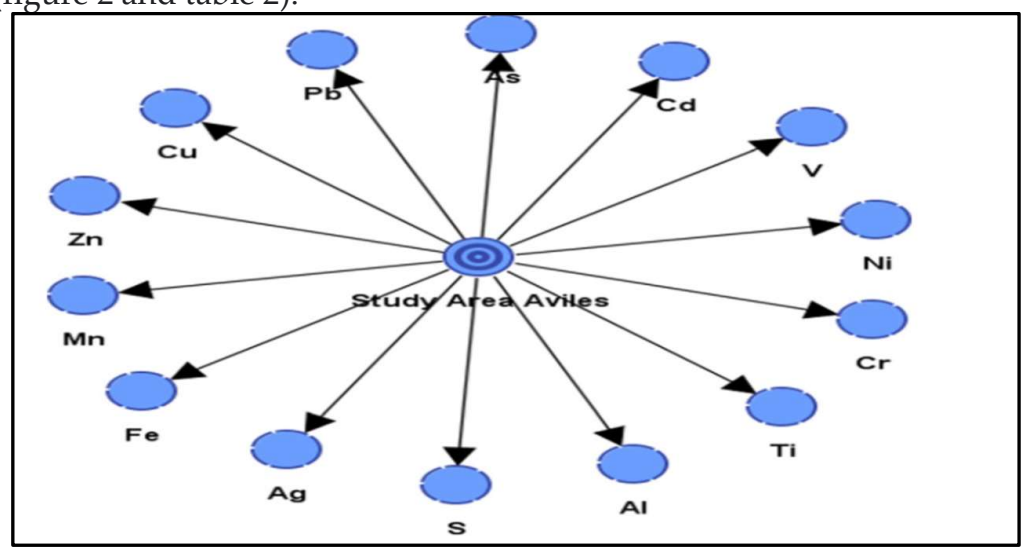

Figure 2. Impact assessment of the main metals in oil polluted areas [15].

An analysis of the effects of metals found in soils in areas where there have been oil mines, was performed by A. R. Karbassi [16,17,18]:

After a pollution, the analyzes must indicate if there are traces of petroleum product (THP), radioactive elements and especially metals. 
For the analysis of the environmental impact of metal pollution from the exploitation of oil fields, a variant of risk composition based on Baysian networks is proposed [19], starting from the relation:

$$
P(x)=P\left(X_{1}, X_{2}, X_{3}, \ldots, X_{n}\right)=\prod_{i=1}^{n} P\left(\frac{X_{i}}{X_{j(i)}}\right),
$$

Where $X_{j(i)}$ are data taken from the acyclic graph of the variables $X_{i}$.

Table 2. Concentration of approved metals in soil pollution (mg / kg dry matter) [21,22,23,24]

\begin{tabular}{cccc}
\hline Metals & $\begin{array}{c}\text { Normal } \\
\text { values }\end{array}$ & $\begin{array}{c}\text { Threshold sensitive area } \\
\text { alert/less sensitive }\end{array}$ & $\begin{array}{c}\text { Intervention threshold } \\
\text { sensitive areas/less } \\
\text { sensitive }\end{array}$ \\
\hline $\mathrm{Cu}(\mathrm{mg} / \mathrm{kg})$ & 20 & $100-250$ & $200-500$ \\
\hline $\mathrm{Pb}(\mathrm{mg} / \mathrm{kg})$ & 20 & $50-250$ & $100-1000$ \\
\hline $\mathrm{Zn}(\mathrm{mg} / \mathrm{kg})$ & 100 & $300-700$ & $600-1500$ \\
\hline $\mathrm{Ag}(\mathrm{mg} / \mathrm{kg})$ & 2 & $10-20$ & $20-40$ \\
\hline $\mathrm{Ni}(\mathrm{mg} / \mathrm{kg})$ & 20 & $75-200$ & $250-500$ \\
\hline $\mathrm{Mn}(\mathrm{mg} / \mathrm{kg})$ & 900 & $1500-2000$ & $25-50$ \\
\hline $\mathrm{As}(\mathrm{mg} / \mathrm{kg})$ & 5 & $15-25$ & $5-10$ \\
\hline $\mathrm{Cd}(\mathrm{mg} / \mathrm{kg})$ & 1 & $3-5$ & $200-400$ \\
\hline $\mathrm{V}(\mathrm{mg} / \mathrm{kg})$ & 50 & $100-200$ & $300-600$ \\
\hline $\mathrm{Cr}(\mathrm{mg} / \mathrm{kg})$ & 30 & $100-300$ & $1000-20000$ \\
\hline $\mathrm{S}(\mathrm{mg} / \mathrm{kg})$ & - & $400-5000$ & \\
\hline
\end{tabular}

Muller designed a pollution index also called Igeo [25] and defined by the equation:

$$
\text { geo }=\log 2 \frac{C_{n}}{1,5 \cdot B_{n}}
$$

Where:

$C_{n}$ is the metal concentration measured in the sample collected,

$B_{n}$ - metal concentration as reference,

1,5 - a calculation factor, .

Another model for determining pollution classes was described by Enrich-ment [26] in relation to:

$$
E F=\frac{\left(\frac{C_{n}}{C_{M n}}\right) \text { analysis sample }}{\left(\frac{C_{n}}{C_{M n}}\right) \text { sample analysis-soil notpollution }}
$$

$C_{M n}$ is the concentration of manganese in the soil sample taken,

Tables 3 and 4 show the pollution classes for the two mathematical models presented above.

Table 3. Pollution classes according to the Igeo index [27]

\begin{tabular}{cc}
\hline Igeo Index & Pollution type \\
\hline Igeo $\leq 0$ & Reduced pollution \\
\hline Igeo $=0-1$ & Normal values \\
\hline Igeo $=1-2$ & Sensitive area alesrt threshold \\
\hline Igeo $=2-3$ & Less sensitive area alert threshold \\
\hline Igeo $=3-4$ & Intervention threshold less sensitive area \\
\hline Igeo $=4-5$ & Extreme pollution \\
\hline Igeo $\geq 5$ & Another method of determining ecological risk measurement levels is re-presented \\
by the relationships between the ecological risk description and the risk index $[28,29]$.
\end{tabular}




$$
\begin{aligned}
& E E_{r}^{i}=T_{r}^{i} \cdot \frac{C_{i}}{C_{0}{ }^{\prime}} \\
& R I=\sum_{i=1}^{n} T_{r}^{i} \cdot \frac{C_{i}}{C_{0}{ }^{\prime}}
\end{aligned}
$$

$C_{i}$ is the metal concentration in the analyzed sample,

$C_{0}$ - the metal concentration in the control sample,

$T_{r}^{i}$ - toxicity factor, (toxicity factor is $A s=10, C u=P b=N i=5, Z n=M n=1, C r=2$ ),

$E_{r}^{i}$ it is the ecological risk factor,

$R I$ represents the risk index of the presence of metals in the soil.

Table 4.Pollutin classes accordin to the Enrichment index - EF [27]

\begin{tabular}{cc}
\hline Level EF & Pollution level \\
\hline $\mathrm{EF} \leq 0$ & Reduced pollution \\
\hline $\mathrm{EF}=0-1$ & Normal values \\
\hline $\mathrm{EF}=1-2$ & Sensitive area alesrt threshold \\
\hline $\mathrm{EF}=2-3$ & Less sensitive area alert threshold \\
\hline $\mathrm{EF}=3-4$ & Intervention threshold sensitive area \\
\hline $\mathrm{EF}=4-5$ & Extreme pollution \\
\hline $\mathrm{EF} \geq 5$ &
\end{tabular}

Table 5. Pollutin classes accordin to the ER and RI index [30,31,32]

\begin{tabular}{ccccc}
\hline Level ER & Value ER & Risk & Level RI & Risk \\
\hline 0 & $<40$ & Reduced & $<110$ & Reduced \\
\hline 1 & $40-80$ & Moderate & $110-200$ & Moderate \\
\hline 2 & $80-160$ & Considerable & $200-400$ & Considerable \\
\hline 3 & $160-320$ & Big & $>400$ & Big \\
\hline 4 & $>320$ & Catastrophic & \\
\hline
\end{tabular}

\section{Results}

In order to analyze the pollution status of a land, we took samples from an area where there were oil exploitations, the results being presented in table 6 and figure 3 .

Table 6. Soil sample position

\begin{tabular}{cl}
\hline Nr. crt. & \multicolumn{1}{c}{ Measurenment point } \\
\hline 1. & Parking lot \\
\hline 2. & Vertical tank $250 \mathrm{mc}$, \\
\hline 3. & Buried tank \\
\hline 4. & Vertical tank $200 \mathrm{~m}^{3}$, salt water \\
\hline 5. & Vertical tank $20 \mathrm{~m}^{3}$, oil and water \\
\hline 6. & Vertical tank $20 \mathrm{~m}^{3}$, oil and water \\
\hline 7. & Oil, gas and water pipelines keyboard \\
\hline 8. & Vertical separator oil, water, gas 3,85 $\mathrm{m} 3-8 \mathrm{bar}$ \\
\hline 9. & Vertical separator oil, water, gas \\
\hline 10. & Vertical separator oil, water, gas 3,85 $\mathrm{m} 3-8$ bar \\
\hline 11. & Vertical separator oil, water, gas \\
\hline 12. & Oil, gas and water pipelines keyboard
\end{tabular}




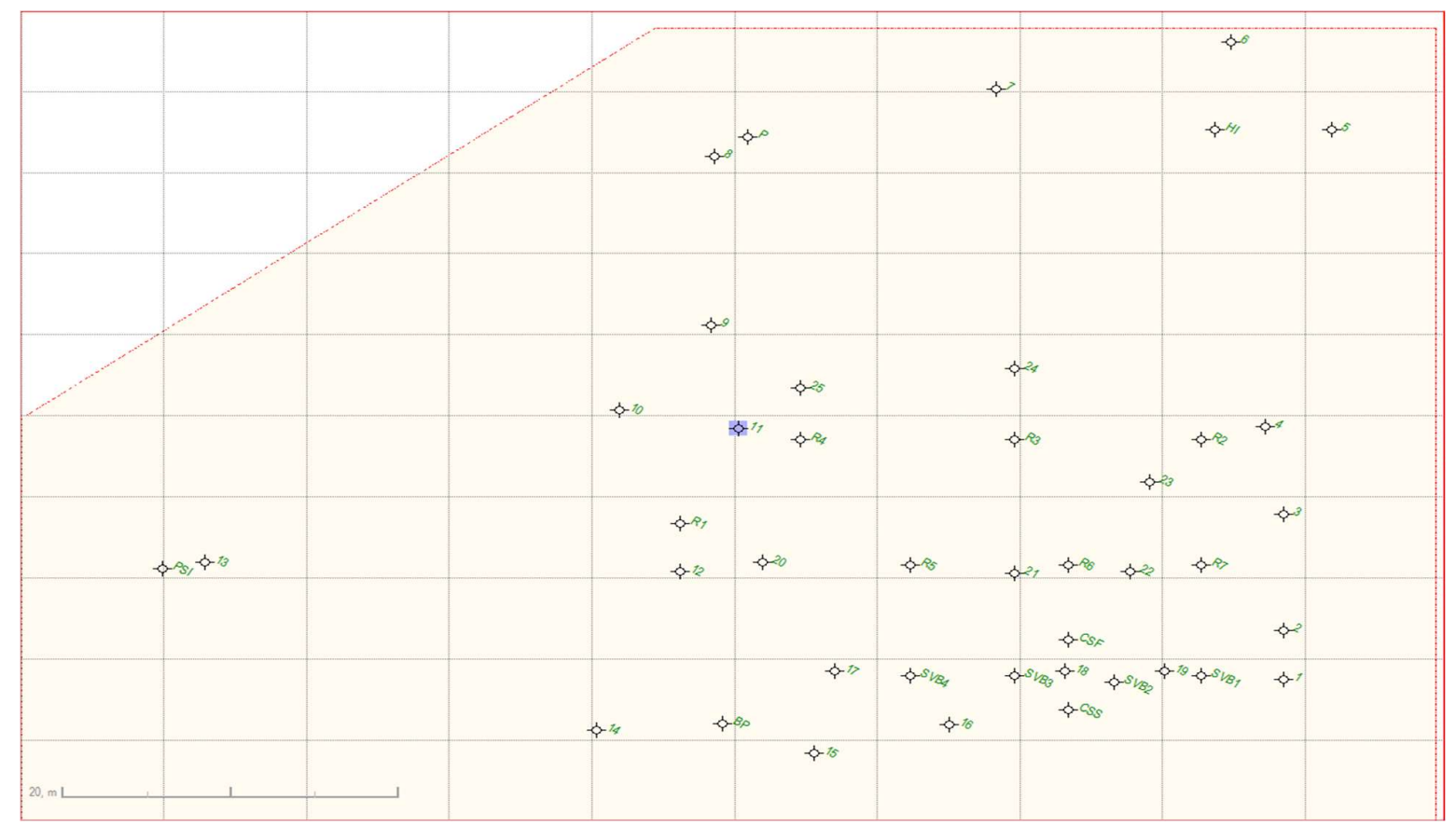

Figure 3. ketch of the analysis area with the presentation of the measurement and sampling points

Table 6. Metal content in the analyzed area (Moinești) $(\mathrm{mg} / \mathrm{kg})$

\begin{tabular}{cccccccc}
\hline Location & $\mathbf{P b}$ & $\mathbf{N i}$ & $\mathbf{V}$ & $\mathbf{C d}$ & $\mathbf{Z n}$ & $\mathbf{A g}$ & $\mathbf{C u}$ \\
\hline 1 & 20 & 170 & 120 & 0,60 & 170 & 1,8 & 150 \\
\hline 2 & 17 & 150 & 100 & 0,50 & 200 & 2,0 & 190 \\
\hline 3 & 23 & 190 & 150 & 0,80 & 268 & 1,7 & 180 \\
\hline 4 & 27 & 195 & 190 & 0,50 & 240 & 2,2 & 120 \\
\hline 5 & 16 & 120 & 200 & 1,05 & 115 & 3,6 & 200 \\
\hline 7 & 23 & 130 & 180 & 0,44 & 110 & 3,5 & 198 \\
\hline 8 & 25 & 140 & 185 & 0,38 & 450 & 2,2 & 159 \\
\hline 9 & 25 & 160 & 150 & 0,48 & 328 & 4,9 & 190 \\
\hline 10 & 23 & 190 & 195 & 0,25 & 338 & 3,9 & 199 \\
\hline 11 & 21 & 180 & 178 & 0,95 & 125 & 2,8 & 197 \\
\hline 12 & 81 & 162 & 146 & 0,58 & 700 & 2,7 & 192 \\
\hline Min & 35 & 190 & 188 & 0,65 & 265 & 2,9 & 188 \\
\hline Max & 16 & 120 & 100 & 0,38 & 110 & 1,7 & 120 \\
\hline $\begin{array}{c}\text { Mediate } \\
\text { Dispersion }\end{array}$ & 28 & 164,75 & 165,17 & 0,60 & 275,75 & 2,85 & 18,25 \\
\hline $\begin{array}{c}\text { Standard } \\
\text { deviation }\end{array}$ & 24,29 & 52,75 & 51,70 & 0,27 & 227,55 & 1,21 & 60,17 \\
\hline $\begin{array}{c}\text { Coefficient } \\
\text { of variation }\end{array}$ & 0,97 & 0,26 & 0,34 & 0,69 & 2,54 & 0,80 & 0,37 \\
\hline $\begin{array}{c}\text { Control } \\
\text { sample } \\
\text { value }\end{array}$ & 25 & 200 & 150 & 0,40 & 90 & 1,5 & 160 \\
\hline Cluj Value & 0,8 & 10 & 70 & 0,005 & 4,21 & 0,01 & 0,75 \\
\hline & & & & & & & \\
\hline
\end{tabular}




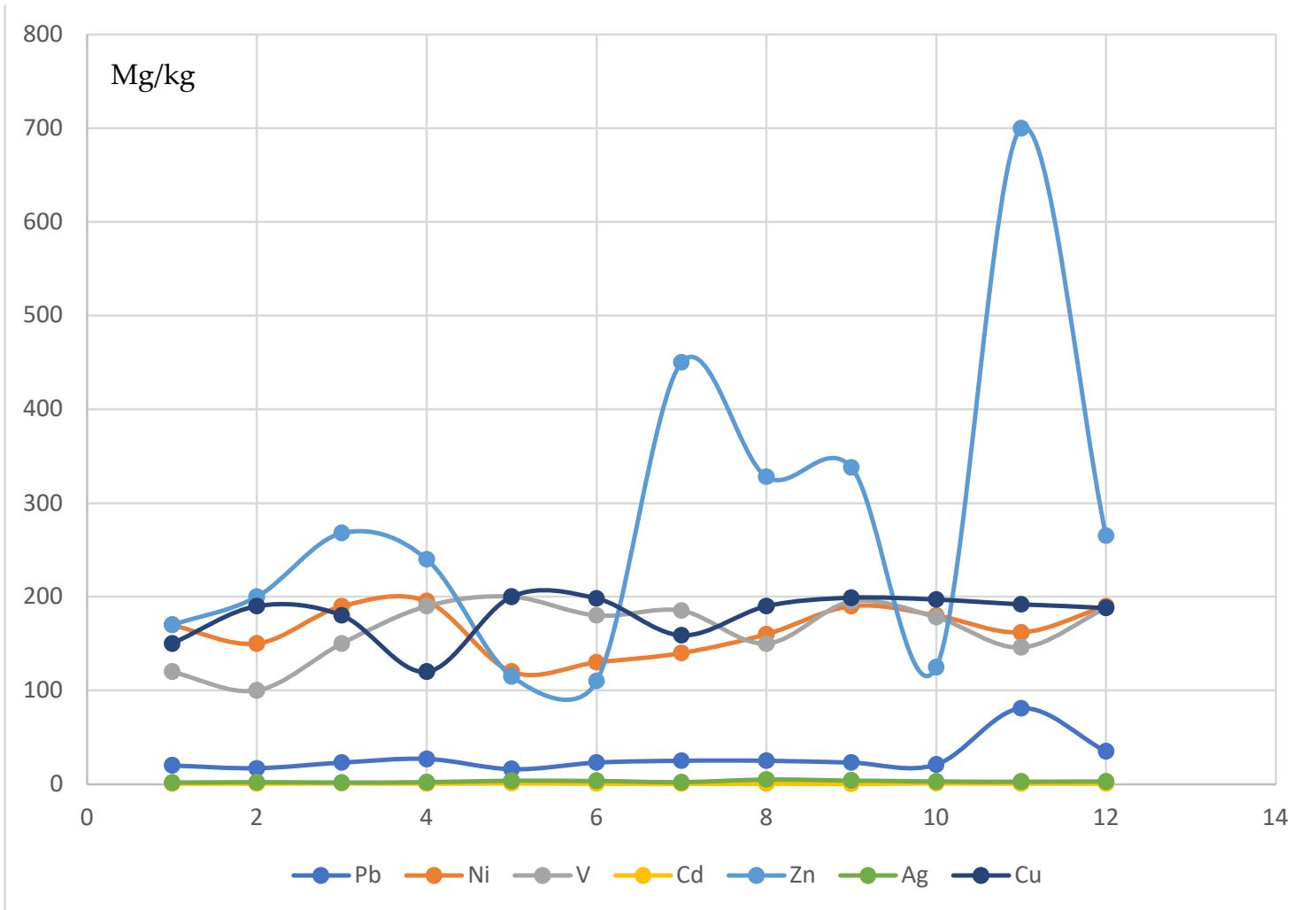

Figure 4. Metals contents in soil sample

The results of applying the method based on the Igeo pollution index (relation 2), respectively the ecological risk and the risk index (relations 4.5) are explained in tables 7 and 8 .

Table 7. Pollution index to $\mathrm{Pb}, \mathrm{Ni}, \mathrm{V}$

\begin{tabular}{|c|c|c|c|c|c|c|c|c|c|c|}
\hline Locațion & $\mathbf{P b}$ & Igeo & $\mathrm{EE}$ & $\mathrm{Ni}$ & Igeo & $\mathrm{EE}$ & $\mathbf{V}$ & & Igeo & $\mathrm{EE}$ \\
\hline 1 & 20,00 & $-0,91$ & 4,00 & 170,00 & $-0,82$ & 4,25 & 120,00 & - & 0,91 & 4,00 \\
\hline 2 & 17,00 & $-1,14$ & 3,40 & 150,00 & $-1,00$ & 3,75 & 100,00 & - & 1,17 & 3,33 \\
\hline 3 & 23,00 & $-0,71$ & 4,60 & 190,00 & $-0,66$ & 4,75 & 150,00 & - & 0,58 & 5,00 \\
\hline 4 & 27,00 & $-0,47$ & 5,40 & 195,00 & $-0,62$ & 4,88 & 90,00 & - & 0,24 & 6,33 \\
\hline 5 & 16,00 & $-1,23$ & 3,20 & 120,00 & - 1,32 & 3,00 & 200,00 & - & 0,17 & 6,67 \\
\hline 6 & 23,00 & - 0,71 & 4,60 & 130,00 & $-1,21$ & 3,25 & 180,00 & - & 0,32 & 6,00 \\
\hline 7 & 25,00 & $-0,58$ & 5,00 & 140,00 & $-1,10$ & 3,50 & 185,00 & - & 0,28 & 6,17 \\
\hline 8 & 25,00 & - 0,58 & 5,00 & 160,00 & - 0,91 & 4,00 & 150,00 & - & 0,58 & 5,00 \\
\hline 9 & 23,00 & - 0,71 & 4,60 & 190,00 & $-0,66$ & 4,75 & 195,00 & - & 0,21 & 6,50 \\
\hline 10 & 21,00 & $-0,84$ & 4,20 & 180,00 & $-0,74$ & 4,50 & 178,00 & - & 0,34 & 5,93 \\
\hline 11 & 81,00 & 1,11 & 16,20 & 162,00 & $-0,89$ & 4,05 & 146,00 & - & 0,62 & 4,87 \\
\hline 12 & 35,00 & $-0,10$ & 7,00 & 190,00 & $-0,66$ & 4,75 & 188,00 & - & 0,26 & 6,27 \\
\hline $\begin{array}{l}\text { Control } \\
\text { sample } \\
\text { value }\end{array}$ & 25,00 & & & 200,00 & & & 150,00 & & & \\
\hline RI & & & 67,2 & & & 49,4 & & & & \\
\hline
\end{tabular}


Table 8. Pollution index to $\mathrm{Cd}$ si $\mathrm{Zn}$

\begin{tabular}{ccccccc}
\hline Locațion & Cd & Igeo & EE & Zn & Igeo & EE \\
\hline 1 & 0,60 & $-0,00$ & 7,50 & 170,00 & 0,33 & 9,44 \\
\hline 2 & 0,50 & $-0,26$ & 6,25 & 200,00 & 0,57 & 11,11 \\
\hline 3 & 0,80 & $-0,42$ & 10,00 & 268,00 & 0,99 & 14,89 \\
\hline 4 & 0,50 & $-0,26$ & 6,25 & 240,00 & 0,83 & 13,33 \\
\hline 5 & 1,05 & 0,81 & 13,13 & 115,00 & $-0,23$ & 6,39 \\
\hline 6 & 0,44 & $-0,45$ & 5,50 & 110,00 & $-0,30$ & 6,11 \\
\hline 7 & 0,38 & $-0,66$ & 4,75 & 450,00 & 1,74 & 25,00 \\
\hline 8 & 0,48 & $-0,32$ & 6,00 & 328,00 & 1,28 & 18,22 \\
\hline 9 & 0,25 & $-1,26$ & 3,13 & 338,00 & 1,32 & 18,78 \\
\hline 10 & 0,95 & 0,66 & 11,88 & 125,00 & $-0,11$ & 6,94 \\
\hline 11 & 0,58 & $-0,05$ & 7,25 & 700,00 & 2,37 & 38,89 \\
\hline 12 & 0,65 & 0,12 & 8,13 & 265,00 & 0,97 & 14,72 \\
\hline $\begin{array}{c}\text { Control } \\
\text { sample } \\
\text { value }\end{array}$ & 0,40 & & & & & \\
\hline RI & & & 89,75 & & & 183,83
\end{tabular}

Table 9. Pollution index to pentru Ag si Cu

\begin{tabular}{rcccccc}
\hline Locație & Ag & Igeo & EE & Cu & Igeo & EE \\
\hline 1 & 1,80 & $-0,32$ & 6 & 150 & $-0,67$ & 4,68 \\
\hline 2 & 2,00 & $-0,16$ & 6,66 & 190 & $-0,33$ & 5,93 \\
\hline 3 & 1,70 & $-0,40$ & 5,66 & 180 & $-0,41$ & 5,62 \\
\hline 4 & 2,20 & $-0,03$ & 7,33 & 120 & -1 & 3,75 \\
\hline 5 & 3,60 & 0,67 & 12 & 200 & $-0,26$ & 6,25 \\
\hline 6 & 3,50 & 0,63 & 11,66 & 198 & $-0,27$ & 6,18 \\
\hline 7 & 2,20 & $-0,03$ & 7,33 & 159 & $-0,59$ & 4,96 \\
\hline 8 & 4,90 & 1,12 & 16,33 & 190 & $-0,33$ & 5,93 \\
\hline 9 & 3,90 & 0,79 & 13 & 199 & $-0,27$ & 6,21 \\
\hline 10 & 2,80 & 0,31 & 9,33 & 197 & $-0,28$ & 6,15 \\
\hline 11 & 2,70 & 0,26 & 9 & 192 & $-0,32$ & 6 \\
\hline 12 & 2,90 & 0,36 & 9,66 & 188 & $-0,35$ & 5,87 \\
\hline $\begin{array}{c}\text { Control } \\
\text { sample } \\
\text { value }\end{array}$ & 1,50 & & & 160 & & \\
\hline RI & & & 114 & & & \\
\hline
\end{tabular}

\section{Discussion}

Oil exploration can also create accidental pollution with heavy metals.

Even if the concentration of total hydrocarbons in the soil is within the limits that do not require intervention for depollution, rather high concentrations of metals have been determined.

The analyzes found that the metals were adsorbed by the soil (through plants) and in the control sample area collected from more than $1 \mathrm{~km}$ away from the crude oil exploitation area. 
Crude oil extraction areas are usually located at fairly large distances from human settlements, but the presence of metals in the soil can lead to their leaching in transitional waters (groundwater).

Also, in the analyzed plants, metal concentrations were discovered, which makes it necessary to determine the metallic elements in the case of the analysis of an oil exploitation area, under ecological reconstruction.

The plants, as seen especially in the control sample, take the metals from the air, being transferred to the soil.

For the treatment of the soil, in the analyzed area marigolds and lettuce were used as crops.

It is recommended not to use these vegetable products.

\section{Conclusions}

It is observed that the pollution with metals, coming from crude oil, is present in the extraction area, being over 10 times bigger than a residential area.

All samples collected have determined values of the amount of metals within the control limits.

Depollution intervention is not recommended, but it is recommended to maintain agricultural crops that naturally treat the removal of metals.

Lead pollution is present especially in the area of the biphasic separator, where the elimination of gases in the atmosphere, due to the opening of the safety valve and the nontightening of the valves created the possibility to remove metals in the exhaust gases

It's an alert threshold.

Zinc pollution is present in areas where gas leaks have occurred, the area being at moderate risk in operation.

As can be seen, metal pollution is only monitored in three cases, with the amounts of metals in the soil showing close values in the test sample.

Also, the analysis of the risk in operation by the two methods is very useful, the results being similar comparative.

Author Contributions: Conceptualization, A.D. and T.C.; methodology, O.S.; software, T.C.; validation, A.D., O.S. and A.S.; formal analysis, T.C.; investigation, T.C.; resources, T.C.; data curation, T.C.; writing-original draft preparation, T.C.; writing - review and editing, T.C.; visualization, A.D.; supervision, O.S.; project administration, T.C.; funding acquisition, T.C. All authors have read and agreed to the published version of the manuscript.

Conflicts of Interest: "The authors declare no conflict of interest.".

\section{References}

1. Chis T.; Petrache M.; Jugastreanu C. Oil pollution of groudwater in Dobruja Area. Quest Journals of Research in Environmental and Earth Sciences 2021, Volume 7, 50-61.

2. Koncsag C.I. Chemistry of oil. Ovidius University Press, Constanta, Romania 2003; pp 45-90.

3. Hagen J. Industrial Catalysis. A practical approach. Wiley-VCH, England, 2006; pp. 197-207.

4. Speight J.J. Petroleum Chemistry and Refining, Taylor and Francis, U.S.A,1997; pp. 202-222.

5. Yen T.F., Structure of Petroleum Asphaltene and Its Significance,1974, Energy Sources, 1:4, pp. 447-463, DOI: 10.1080/00908317408945937.

6. Muniyappan R., Porphyrins in petroleum, Journal of Chemical Education 195532 (5), pp. 277, DOI: 10.1021/ed032.

7. Almejbel A.S. ; Lash T.D. Synthesis of 2-bromo- and 2-phenyl-neo-confused porphyrins, Organic E Biomolecular Chemistry, 2020, Volume 37.

8. Fakher, S. ;Ahdaya, M. ; Elturki, M. et al. Critical review of asphaltene properties and factors impacting its stability in crude oil. J Petrol Explor Prod Technol 10, 1183-1200 (2020). https://doi.org/10.1007/s13202-019-00811-5.

9. Munirah A. Z. ; Kamaruzaman W. Ah.; Ananthy R.; Catrinab Ng. Concentration of heavy metals in virgin, used, recovered and waste oil: a spectroscopic study. International Conference on Environmental Forensics 2015, pp. 201 - 204 (iENFORCE2015), Procedia Environmental Sciences 30. 
10. Petrache St. Environmental risk management at the end of onshore oil operations, Ph.D. Thesis, Oil and Gas University, 2021, pp.190-220, Ploiesti.

11. Albuquerque, M.T.D.; Gerassis, S.; Sierra C.; Taboada J.; Martin J.E.; Antunes I.M.H.R.; Gallego J.R., Developing a new Bayesian Risk Index for risk evaluation of soil contamination. Sci. Total Environ. 2017,603-604, pp. 167-177.

12. Bazlamaçci C.F.; Hindi K.S.Minimum-weight spanning tree algorithms. A survey and empirical study, 2001. Comput. Oper. Res., 28, pp. 767-785.

13. Aguilera P.A.; Fernández A.; Fernández R.; Rumí R.; Salmerón A. Bayesian networks in environmental modelling,2011, Environ. Model. Softw., 26, pp. 1376-1388.

14. Cocârță D. M.; Stoian M. A.; Karademir A. Crude Oil Contaminated Sites: Evaluation by Using Risk Assessment Approach, 2017, Sustainability, Vol. 9, No. 8, www.mdpi.com.

15. CCME, 2007. Canadian Soil Quality Guidelines for the Protection of Environmental and Human Health: Summary Tables. Environment Canada, National Guidelines and Standards Office (No. 1299, ISBN 1-896997-34-1).

16. Avram L., Oil drilling, 2011, Oil and Gas Publishing House, Ploieşti.

17. Karbassi A.R.; Abduli M. A.; Mahin Abdollahzadeh E., Sustainability of energy production and use in Iran, 2007, Energy Policy, 35(10): pp.5171-5180.

18. Karbassi A. R.; Pazoki M., Environmental qualitative assessment of rivers sediments, 2015, Global J.Environ. Sci. Manage.,1(1): pp. 109-116.

19. Karbassi A.R.; Kachoosangi T.F.; Ghazban F.; Ardestani M.. Association of trace metals with various sedimentary phases in dam reservoirs, 2011, Int. J. Environ. Sci. Tech., 8(4): pp.841-852.

20. Lahr J., Kooistra L., Environmental risk mapping of pollutants: state of the art and communication aspects. Sci. Total Environ., 408:3899-3907, 2010, http://dx.doi.org/10. 1016/j.scitotenv.2009.10.045.

21. Recommended Canadian Soil Quality Guidelines, Canadian Council of Ministers of the Environment, 1997, Winnipeg, Canadian Council of Ministers of the Environment 2004.

22. Global assessment of soil pollution, 2021, FAO and UNEP.

23. Pérez A.P.; Eugenio N.R. Status of local soil contamination in Europe, 2021, JRC Science Hub.

24. On the management of potentially contaminated and contaminated sites, Law 74 - April, 2019, Romanian Parliament.

25. McDonald K.S.; Ryder D.S.; Tighe M. Developing best-practice Bayesian belief networks in ecological risk assessments for freshwater and estuarine ecosystems: a quantitative review, 2015, J. Environ. Manag., 154, pp. 190-200.

26. Moen J.; Ale B.J.M. Risk maps and communication, 1998, J. Hazard. Mater. 61, pp. 271-278.

27. Nilin J.; Moreira L.B.; Aguiar J.E.; Marins R.; Moledo de Souza Abessa D.; Monteiro da Cruz Lotufo T.; Costa-Lotufo L.V.; Sediment quality assessment in a tropical estuary: The case of Ceará River, Northeastern Brazil, 2013, Mar. Environ. Res.,91, pp.89-96.

28. Pejman A.; Nabi Bidhendi G.; Ardestani M.; Saeedi M.; Baghvand A. A new index for assessing heavy metals contamination in sediments: A case study,2015, Ecol. Indic., 58, pp. 365-373.

29. Chai L.; Li H.; Yang Z.; Min X.; Liao Q.; Liu Y.; Men S.; Yan Y.; Xu J. Heavy metals and metalloids in the surface sediments of the Xiangjiang River, Hunan, China: Distribution, contamination, and ecological risk assessment, Environ. Sci. Pollut. Res., 2017, 24, pp. 874-885.

30. Ke X.; Gui S.; Huang H.; Zhang H.; Wang C.; Guo W. Ecological risk assessment and source identification for heavy metals in surface sediment from the Liaohe River protected area, China,2017, Chemosphere, 175, pp.473-481.

31. Wang Y.; Hu J.; Xiong K.; Huang X.; Duan S. Distribution of Heavy Metals in Core Sediments from Baihua Lake, 2012,Procedia Environ. Sci., 16, pp. 51-58.

32. Alyazichi Y.M.; Jones B.G.; McLean E.; Pease J.; Brown H. Geochemical Assessment of Trace Element Pollution in Surface Sediments from the Georges River, Southern Sydney, Australia, 2017,Arch. Environ. Contam. Toxicol. ,72, pp. $247-259$.

33. Ma L.; Yang Z.; Li L.; Wang L.. Source identification and risk assessment of heavy metal contaminations in urban soils of Changsha, a mine-impacted city in Southern China, 2016, Environ. Sci. Pollut. Res., 23, pp. 17058-17066. 